\title{
Study of Erythropoeitin on IGM serum levels in HCV positive patients on regular HD
}

\author{
Khaled Abo Seif (1), Mona Hosny (1) And Ahmed Aboud(2) \\ Internal Medicine Department, Faculty of Medicine, \\ Ain Shams University (1), Shubra Municipal Hospital (2)
}

\begin{abstract}
Both uremia and HD process cause immunosuppression in HD patients. There was significant increase of total serum IgG and IgM levels found in patients with chronic HCV compared with healthy controls. There is evidence pointing to direct effect of rHuEPO upon B cells. High doses of recombinant human erythropoietin ( $\mathrm{rHu}$ EPO) enhanced in vitro Ig production and proliferation of various plasma cell lines, as well as human plasma cells generated in vitro. Study was conducted at hemodialysis Unit of Shubra Municipal hospital between August 2010 to February 2011. $30 \mathrm{HCV}$ positive patients on regular hemodialysis were included in study, using bicarbonate dialysate and polysulfone membrane dialyser, for 4 hours 3 times weekly. Patients were divided into 2 groups: first group: 15 patients on EPO therapy. $4000 \mathrm{IU} /$ week and second group not taking EPO for all patients full clinical examination was done, CBC, BUN, serum creatinine, ALT, AST, serum albumin and serum IgM by ELISA (quantitative assay), were done.

There was no significant difference between 2 groups as regards age, sex distribution, WBC count, ALT, AST, serum creatinine, BUN and IgM serum level. First group had borderline significant higher Hgb and Hct than second group $(\mathrm{p}=0.056)$. Females didn't have higher serum IgM level than males $(\mathrm{p}=0.403)$. All correlations of IgM serum level to other parameters of study were irrelevant. Uremia seems to protect ESRD patients on regular HD from complications of $\mathrm{HCV}$ and also EPO effect on Ig serum levels.
\end{abstract}

Key words : Erythropoeitin- IgM -HCV - Hemodialysis.

\section{Introduction}

Uremia is associated with a state of immune dysfunction characterized by immunodepression that leads to high prevalence of infections as well as by immune activation resulting in inflammation (Kiechl et al., 2002).

Improper immunological parameters of both humoral and cellular immunity in CKD patients seem to be deepened by hemodialysis (HD) process (Liwosca et al., 2011b). Patients with renal disease have been at increased risk of acquiring $\mathrm{HCV}$ because of prolonged vascular access as well as the potential for exposure to infected patients and contaminated equipment (Fabrizi et al., 2007).

Several studies have provided experimental evidence of disorders of both cellular and humoral immunity in chronic hepatitis C patients (Lotfy et al., 2006).
$\mathrm{HCV}$ infection is strongly associated with mixed cryoglobulinemia (MC), a benign disorder characterized by the proliferation of $\mathrm{B}$ lymphocytes producing polyclonal $\mathrm{IgG}$ or monoclonal IgM with rehumatioid factor (RF) activity that characteristically may precipitate at low temperatures (Fazi et al., 2010).

Besides B-cell activation (non-antigenspecific and antigen-specific), HCV seems to infect B lymphocytes directly (Bokle and Sepp, 2010).

Correction of anemia and maintenance of stable hemoglobin levels using erythropoesis stimulating agents (ESA) is an important aspect of ESRD management (Kalantar-Zadeh and Aronoff, 2009). Epo therapy leads to improved humoral immune response, either directly or via Tcells help (Prutchi-Sagiv et al., 2005). 
Epo treatment was associated with enhanced lymphocyte activity of both Tand B-cells (Lifshitz et al., 2010).

Erythropoietin-receptor (EPO-R) presence on all populations of immune cells implies that EPO/rhEPO can influence lymphocytes, monocyte san granulocytes directly and somehow modulate their immunological responses (Liwoska et al., 2011 a).

High doses of rHu EPO enhanced in vitro immunolglobulin production of various plasma cell lines, as well as human plasma cell generated in vitro (Prutchi-Sagiv et al., 2005).

The uremic patient on regular hemodialysis (HD) is subjected to a wide range of immune modulators including the uremic sate per se, multiple transfusions and exposure to bio incompatible materials and endotoxins. Erythropoietin (EPO) therapy may raise concern about its potential influence on this complex Scenario (William et al., 1998).

\section{Aim of work}

Is to determine the effect of erythropoietin on IgM level in ESRD patients infected with $\mathrm{HCV}$ on regular hemodialysis as IgM is one of the markers of cryoglobulinemia.

\section{Patients and methods}

This study was conducted at hemodialysis unit of Shubra Munieipal Hospital between august 2010 to February 2011. it was conducted on 30 ESRD hepatitis $C$ positive patients on regular hemodialysis with bicarbonate dialysate and polysulfone membrane dialyser, three times per week. All patients had chronic hepatitis C infection for less than 10 years with liver enzymes less than two fold increase above normal (specially ALT) and last blood transfusion more than 30 days ago.

These patients were divided into 2 groups First group: Includes 15 ESRD hepatitis C positive patients on regular $\mathrm{HD}$ and on erythropoietin therapy. Patients of this group were administered erythropoietin dose of 4000 IU/week.

Second group: Includes 15 ESRD hepatitis $\mathrm{C}$ positive patients on regular HD and not on erythropoietin therapy.
We excluded from the study patients with history of DM, autoimmune and allergic diseases.

Patients with hepatitis $\beta$ virus confection, dialysis vascular access infection, history of paraproteinemia, systemic vasculitis, acute hepatitis liver cell failure or chronic infections other than $\mathrm{HCV}$ and chronic inflammatory diseases were excluded from the study.

All patients were subjected to full history and complete physical examination, complete blood count, blood urea nitrogen, serum creatinine, liver enzymes (AST and ALT), serum albumin, and serum IgM by ELISA (quantitative assay).

\section{Methods}

\section{1- Creatinine}

This assay is a kinetic method (Yatzidis, 1974).

\section{Assay principle}

Creatinine in alkaline solutions react with picrate to form a colored complex. The rate of complex formation is measured photometrically at $492 \mathrm{~nm}$.

\section{Calculations}

A2-A2: A(specimen)-A (standard)

* Concentration of creatinine in serum or plasma $(\mathrm{mg} / \mathrm{dL})=\frac{\text { A Speacimen }}{A s \tan \text { dard }} X 2$

\section{2- Urea}

This procedure is enzymatic-spectrophotometric (Tabacco et al., 1979).

\section{Assay principle}

Urea in the sample originates by means of the coupled reactions described below, a colored complex that can be measured by spectrophotometry : urea $+\mathrm{H}_{2} \mathrm{O} \stackrel{\text { Urea }}{\longrightarrow}$ $2 \mathrm{NH}_{4}+\mathrm{CO}_{2}$

$\mathrm{NH} 4+$ salicylate $+\mathrm{NaCLO} \stackrel{\text { nitroprusside }}{\longrightarrow}$ indophenol

\section{Calculations}

The urea calculation in the sample is calculated using the following general formula: 
Urea in sample
$\frac{\text { A Sample }}{\text { As tan dard }}$ XC $S$ tan dard

$\mathrm{X}$ sample dilution factor

Where $\mathrm{c}=$ concentration

\section{3-Albumin (BCG):}

This assay is colori-metric method ( Doumas et al. , 1971).

\section{Assay principle}

In a buffered solution bromo-cresol green forms with albumin, a green colour complex whose intensity is proportional to the amount of albumin present in the specimen calculations:

Albumin Concnetration $(\mathrm{g} / \mathrm{dL})=$ $\frac{\text { A Speacimen }}{\text { As } \tan \text { dard }} X 4$

\section{4- ALT (SGPT)}

Liqui-UV test (Schumann and Klauke, 2003).

\section{Assay principle}

Kinetic method for the determination of ALT activity according to the recommendations of the expert panel of the IFCC (International federation of clinical chemistry) without pyridoxalphosphate activation.

\section{Reaction principle:}

2- Oxo-glutarate+L-alanine $\stackrel{G P T}{\longrightarrow}$ Lglutamate+pyruvate

Pyruvate $+\mathrm{NADH}+\mathrm{H}+\stackrel{L D H}{\longrightarrow} \mathrm{L}-$ lactate $+\mathrm{NAD}^{+}$

\section{5- AST (SGOT)}

Liqui-UVtest (Schumann and Klauke, 2003).

\section{Assay principle}

Kinetic method for the determination of AST activity according to the recommendation of the expert panel of the IFCC (international federation of clinical chemistry) without pyridoxal-phosphate activation reaction principle: 2-Oxoglutarate+L-aspartate $\stackrel{\text { GOT }}{\longrightarrow}$ Lglutamate $=$ oxaloacetate.

\author{
Oxaloacetate $+\mathrm{NADH}+\mathrm{H}+\stackrel{M D H}{\longrightarrow} \mathrm{L}-$ \\ malate $+\mathrm{NAD}^{+}$
}

\section{6- Serum IgM by Elisa (Diagnostic Automatic Inc., 2009).}

Intended use: to quantitate total human immunoglobulin M (IgM).

\section{Principle of procedure}

Solid phase capture sandwich ELISA assay using a Microwell format.

Patients and standard dilutions dilute each serum or plasma specimen to be tested initially 1: 1000 in phosphate buffered saline (PBS) e.g $10 \mu \mathrm{l}$ of specimen into $990 \mathrm{ml}$ of PBS, then subdilute 1:10 with the IgM specimen diluent provided for a final dilution of $1: 10.000$. Prepare serial two fold dilutions of the human IgM standard: neat, 1:2, 1:4, 1:8 etc., with the specimen diluent provided, use the specimen diluent alone as the blank control well.

\section{Assay procedure}

Allow each reagent to reach room temperature before use

1- $\quad$ Add $100 \mu \mathrm{L}$ of diluted specimen or standard to each Microwell.

2- Incubate at room temperature for 60 minutes.

3- Decant and wash each Micowell four times with wash buffer (dilute buffer 1:15 with reagent grade water).

4- $\quad$ Add $100 \mu \mathrm{L}$ of HRP conjugated goat anti-human IgM to each well.

5- Incubate at room temperature for 60 minutes.

6- $\quad$ Decant and wash as in step 3.

7- $\quad$ Add $100 \mu \mathrm{L}$ of TMB/peroxidase substrate and incubate at room temperature for 30 minutes.

8- Terminate the reaction with 100 $\mu \mathrm{L}$ of $0.5 \mathrm{~N}$ sulfuric acid.

9- Zero the MIcrowell reader at $450 \mathrm{~mm}$ using the specimen diluent zero control well.

10- Determine the optical density (O.D.) of the remaining wells.

11- Construct a standard curve using the O.D. values obtained for each of the standards. 
12- Interpolate the unknowns from the standard curve.

Dynamic range $=0.031 \mu \mathrm{g} / \mathrm{ml} .2 .0 \mu \mathrm{g} / \mathrm{ml}$

\section{Statistical analysis}

Statistical presentation and analysis of the present study was conducted, using the mean, standard error, student t-test, chisquare and linear correlation coefficient by SPSS V17. We also used Analysis of variance (ANOVA) test to compare different items in the same group in quantitative data. significant

$$
\mathrm{P} \text {-value } \leq 0.05 \text { is considered }
$$

$* \mathrm{P}$ value $=0.05$ to $<0.1$ is considered borderline significance

$* \mathrm{P}$ value $\leq 0.01$ is considered highly significant significant

* $\mathrm{P}$ value $>0.1$ is considered non-

\section{Results}

On comparing first and second group as regards age, there was no statistically significant difference between $1^{\text {st }}$ group $($ mean $\pm S D=50.533 \pm 8.766$ years $)$ and $2^{\text {nd }}$ group (mean $\pm \mathrm{SD}=51.133 \pm 6.632$ years) using unpaired student $\mathrm{t}$-test $(\mathrm{p}$-value $=$ 0.834 ).

We didn't find a statistically significant difference between $1^{\text {st }}$ and $2^{\text {nd }}$ group as regards sex distribution, (p-value $=0.140$ ) using chi-square test, while females constituted $40 \%$ of $1^{\text {st }}$ group and $66.67 \%$ of $2^{\text {nd }}$ group and the total number of females included in the study constituted $53.33 \%$ of all participants in the study. Males constituted $60 \%$ of 1 st group and $33.33 \%$ of $2^{\text {nd }}$ group with a total of $46.67 \%$ of all participants in the study

Table (1): Comparison of first group and second group as regards serum creatinine

\begin{tabular}{l|c|c|c|c}
\hline \multirow{2}{*}{} & \multicolumn{2}{|c|}{ S. creatinine (mg/dL) } & \multicolumn{2}{c}{ T-test* } \\
\cline { 2 - 5 } & Range & Mean \pm SD & t & p-value \\
\hline First group & $6.100-12.500$ & $10220 \pm 2.066$ & & \\
\hline Second group & $7.000-15.900$ & $9.993 \pm 2.207$ & 0.290 & 0.774 \\
\hline
\end{tabular}

* Unpaired student t-test

Table (2): Comparison of first group and second group as regards blood urea nitrogen

\begin{tabular}{l|c|c|c|c}
\hline \multirow{2}{*}{} & \multicolumn{2}{|c|}{ Blood urea nitrogen $(\mathbf{m g} / \mathbf{d L})$} & \multicolumn{2}{c}{ T-test* } \\
\cline { 2 - 5 } & Range & Mean \pm SD & t & p-value \\
\hline First group & $112.000-184.000$ & $148.400 \pm 21.596$ & & \\
\hline Second group & $107.000-200.000$ & $146.800 \pm 31.122$ & 0.164 & 0.871 \\
\hline
\end{tabular}

* Unpaired student t-test 
Table (3): Comparison of first group and second group as regards AST level in serum

\begin{tabular}{l|c|c|c|c}
\hline \multirow{2}{*}{} & \multicolumn{2}{|c|}{ AST Iu/L } & \multicolumn{2}{c}{ T-test* } \\
\cline { 2 - 5 } & Range & Mean \pm SD & t & p-value \\
\hline First group & $8.000-22.000$ & $13.600 \pm 3.851$ & & \\
\hline Second group & $10.000-21.000$ & $16.467 \pm 2.973$ & -2.282 & 0.030 \\
\hline
\end{tabular}

* Unpaired student t-test

Table (4): Comparison of first group and second group as regards ALT level in serum

\begin{tabular}{l|c|c|c|c}
\hline \multirow{2}{*}{} & \multicolumn{2}{|c|}{ ALT Iu/L } & \multicolumn{2}{c}{ T-test* } \\
\cline { 2 - 5 } & Range & Mean \pm SD & t & p-value \\
\hline First group & $5.000-15.000$ & $8.533 \pm 2.800$ & & \\
\hline Second group & $6.000-15.000$ & $10.200 \pm 2.541$ & -1.707 & 0.099 \\
\hline
\end{tabular}

* Unpaired student t-test

Table (5): Comparison of first group and second group as regards serum albumin

\begin{tabular}{l|c|c|c|c}
\hline \multirow{2}{*}{} & \multicolumn{2}{|c|}{ S. albumin $(\mathbf{g} / \mathbf{L})$} & \multicolumn{2}{c}{ T-test* } \\
\cline { 2 - 5 } & Range & Mean \pm SD & t & p-value \\
\hline First group & $3.100-4.200$ & $3.573 \pm 0.371$ & & \\
\hline Second group & $3.000-4.300$ & $3.593 \pm 0.404$ & -0.141 & 0.889 \\
\hline
\end{tabular}

* Unpaired student t-test

Table (6): Comparison of first group and second group as regards hemoglobin (Hgb) level

\begin{tabular}{l|c|c|c|c}
\hline \multirow{2}{*}{} & \multicolumn{2}{|c|}{ Hgb (g/dL) } & \multicolumn{2}{c}{ T-test* } \\
\cline { 2 - 3 } & Range & Mean \pm SD & t & p-value \\
\hline First group & $7.800-14.500$ & $10.113 \pm 2.144$ & & \\
\hline Second group & $5.700-12.400$ & $8.600 \pm 2.015$ & \multirow{2}{*}{1.992} & 0.056 \\
\hline
\end{tabular}

* Unpaired student t-test 
Study of Erythropoeitin......

Table (7): Comparison of first group and second group as regards hematocrit (Hct) level

\begin{tabular}{l|c|c|c|c}
\hline \multirow{2}{*}{} & \multicolumn{2}{|c|}{ Hct (\%) } & \multicolumn{2}{c}{ T-test* } \\
\cline { 2 - 5 } & Range & Mean \pm SD & t & p-value \\
\hline First group & $20.800-41.700$ & $31.080 \pm 6.487$ & & \\
\hline Second group & $17.300-37.000$ & $26.687 \pm 5.568$ & & \multirow{2}{*}{1.990} \\
\hline
\end{tabular}

* Unpaired student t-test

Table (8): Comparison of first group and second group as regards white blood cells

\begin{tabular}{|c|c|c|c|c|}
\hline & \multicolumn{2}{|c|}{$\mathrm{WBC}\left(\times 10^{9} / \mathrm{L}\right)$} & \multicolumn{2}{|c|}{ T-test* } \\
\hline & Range & Mean \pm SD & $\mathbf{t}$ & p-value \\
\hline First group & $3000.000-87.00$ & $5373.333 \pm 1810.472$ & \multirow{2}{*}{0.430} & \multirow{2}{*}{0.670} \\
\hline Second group & $2100.000-8000.00$ & $5073.333 \pm 2005.516$ & & \\
\hline
\end{tabular}

* Unpaired student t-test

Table (9): Comparison of first group and second group as regards serum IgM level

\begin{tabular}{l|c|c|c|c}
\hline \multirow{2}{*}{} & \multicolumn{2}{|c|}{ IgM $(\mathbf{u g} / \mathbf{m L})$} & \multicolumn{2}{c}{ T-test* } \\
\cline { 2 - 4 } & Range & Mean \pm SD & t & p-value \\
\hline First group & $40.300-213.700$ & $119.467 \pm 61.781$ & & \\
\hline Second group & $43.000-214.500$ & $114.647 \pm 48.536$ & 0.238 & 0.814 \\
\hline
\end{tabular}

* Unpaired student t-test

Table (10): Comparison of IgM level in serum in males and females in both first and second groups together

\begin{tabular}{l|c|c|c|c}
\hline \multirow{2}{*}{ Female } & \multicolumn{2}{|c|}{ IgM $(\mathbf{u g} / \mathbf{m L})$} & \multicolumn{2}{c}{ T-test* } \\
\cline { 2 - 5 } & Range & Mean \pm SD & t & p-value \\
\hline Male & $40.300-213.700$ & $125.025 \pm 52.345$ & & \\
\hline
\end{tabular}

* Unpaired student t-test 
Table (11): Correlation of serum level of IgM and different parameters of the study in first group

\begin{tabular}{|c|c|c|}
\hline \multirow{2}{*}{ First group } & \multicolumn{2}{|c|}{ IgM } \\
\hline & $\mathbf{R}^{*}$ & P-value \\
\hline Age & -0.119 & 0.674 \\
\hline S. creatinine & -0.374 & 0.170 \\
\hline BUN & -0.470 & 0.077 \\
\hline SGOT (AST) & -0.467 & 0.079 \\
\hline SGPT & -0.247 & 0.375 \\
\hline S. albumin & 0.035 & 0.901 \\
\hline EPO dose & 0.242 & 0.384 \\
\hline $\mathrm{Hgb}$ & 0.005 & 0.987 \\
\hline Hct & 0.122 & 0.665 \\
\hline WBC & -0.104 & 0.712 \\
\hline
\end{tabular}

* Linear correlation coefficient $(\mathrm{r})$

Table (12): Correlation of serum level of IgM and different parameters of the study in second group

\begin{tabular}{|c|c|c|}
\hline \multirow{2}{*}{ Second group } & \multicolumn{2}{|c|}{ IgM } \\
\hline & $\mathbf{R}^{*}$ & P-value \\
\hline Age & -0.147 & 0.600 \\
\hline S. creatinine & -0.064 & 0.821 \\
\hline BUN & 0.300 & 0.277 \\
\hline SGOT (AST) & 0.338 & 0.218 \\
\hline SGPT (ALT) & 0.467 & 0.079 \\
\hline S. albumin & -0.085 & 0.762 \\
\hline $\mathrm{Hgb}$ & -0.305 & 0.270 \\
\hline Hct & -0.223 & 0.425 \\
\hline WBC & 0.172 & 0.540 \\
\hline
\end{tabular}

* Linear correlation coefficient (r)

Table (13): Correlation of serum level of IgM and different parameters of the study in both first and second group

\begin{tabular}{l|c|c}
\hline \multirow{2}{*}{$\mathbf{1}^{\text {st }} \boldsymbol{2}^{\text {nd }}$ group } & \multicolumn{2}{|c}{ IgM } \\
\cline { 2 - 3 } Age & -0.131 & P-value \\
\hline S. creatinine & -0.227 & 0.491 \\
\hline BUN & -0.057 & 0.229 \\
\hline SGOT (AST) & -0.167 & 0.766 \\
\hline SGPT (ALT) & 0.034 & 0.377 \\
\hline S. albumin & -0.021 & 0.858 \\
\hline EPO dose & 0.242 & 0.912 \\
\hline Hgb & -0.102 & 0.384 \\
\hline Hct & 0.000 & 0.591 \\
\hline WBC & 0.028 & 1.000 \\
\hline
\end{tabular}

* Linear correlation coefficient (r) 


\section{Discussion}

The depression of the immune response in the uremic patient is global and concerns both humoral and cellular sectors (Foley and Collins, 2007).

Disorders of both innate and adaptive immune systems and functional abnormalities of monocytes, neutrophils and dendritic cells, are directly linked with infection risk in this patient population (Lim et al., 2007).

Death from sepsis is 50 times higher in hemodialysis patients than in the general population even after accounting for other comorbidities. One of the most difficult causes to treat is the development of an acquired immune dysfunction associated with chronic kidney disease (CKD) and dialysis therapy (Geara et al., 2010).

Hepatitis C virus (HCV) is commonly associated with autoimmune disease as extra-hepatic manifestations (EHM).

The most important auto-immune diseases associated with $\mathrm{HCV}$ are mixed essential cryoglobulinemia (MEC) and Sjogren syndrome (SS) (Awad et al., 2011). Increasing evidence suggests that $\mathrm{HCV}$ can interfere with innate immune activation at multiple levels (Jang and Chung, 2010).

$\mathrm{HCV}$ itself seems to be able to stimulate B cells through different pathways and mechanisms (Bokle and Sepp, 2010).

The persistent of stimulation of B cells by viral antigen could be responsible for leading to polyclonal and later to monoclonal expansion of $\mathrm{B}$ cells (Ito et al., 2011).

The highest level of B-lymphocyte stimulator have been found in chronic HCV-infected subjects with clinical and laboratory features of autoimmunity (Bokle and Sepp, 2010).

EPO structure presents elements of cytokines composition and that is why, it is considered that this hormone, a part from its influence on red blood cells system, can regulate immunological responses (Liwoska et al., 2011b).

Studies over the last 12 years demonstrated that erythropoietin is probably able to modulate or amplify some signaling pathways important for human lymphocytes and monocyte functions. There are also many studies demonstrating the role of $\mathrm{rHu}$ EPO in improving immune responses in CRF patients and at the same time suggesting that $\mathrm{rHu}$ EPO may act as an immunomodulating cytokine in the human organism (Liwoska et al., 2011a).

In our study, there was no statistical significant difference as regards age $(\mathrm{P}=$ $0.834)$ and sex distribution $(\mathrm{p}=0.140)$ between the first group with EPO therapy and the second group without EPO therapy. Serum immunoglobulin concentrations tend to increase with age (Gonzalez et al., 2008).

On comparing first and second groups, there was no statistical significant difference as regards serum creatinine levels $(p=0.774)$ and blood urea nitrogen levels $(\mathrm{p}=0.871)$, which means that HCV infection together with concomitant EPO therapy didn't influence these two parameters in ESRD patients on regular HD.

In our study, second group showed higher serum AST levels than first group on EPO therapy $(p=0.03)$. Also, second group showed a borderline significantly higher serum ALT levels than first group ( $\mathrm{p}=$ 0.099). In our study, EPO seems to have an anti-inflammatory response influencing our markers of hepatic inflammation or may be it may have a liver supporting effect. Further studies are needed to elucidate this role using liver biopsy findings.

Compared to non-uremic HCV patients, ESRD patients with chronic hepatitis C have milder hepatic necroinflammation and fibrosis (Trevizoli et al., 2008).

Patients with ESRD and HCV infection displayed normal ALT levels. Indeed ALT levels in these patients were significantly lower than those found in patients infected with $\mathrm{HCV}$ without renal damage but with similar grades and stages of liver alterations. It has been proposed that the increase in hepatocytes of HCV-infected patients with ESRD who are an chronic dialysis produces a hepatoprotective effect (Contreras et al., 2007).

Causes of reduction in ALT activity in these patients are only partially known, such as a reduction in pyridoxal - 5' phosphate, vitamin $\mathrm{B}_{12}$, coenzymes of 
ALT, suppression of AST and ALT synthesis in hepatocytes and an inhibition of AST and ALT released from hepatocytes into the blood stream, as well as the possibility of liver protection by the hepatocyte growth factor, which is higher in patients with chronic renal failure (Lin et al., 2008).

Among HD patients, serum ALT levels are elevated in $4-67 \%$ patients with positive anti-HCV antibodies, $12-31 \%$ of patients with positive HCV-RNA and one third of patients with biopsy proven hepatitis (Perira and Levey, 1997).

Shin et al., (2006) reported on two cases after accidental ten times overdose administration of recombinant human erythropoietin (rHu EPO) up to 318.000 units a day in acute myocardial infarction, that the only side effects they found were elevated liver enzymes and hemoglobin levels. These patients were followed up as out patients and elevated enzymes soon normalized.

In Berglund and Ekblom study (1991), that aimed to evaluate the effect of treatment with subcutaneous recombinant human erythropoietin (rHuEPO), 20-40 $\mathrm{Iu} / \mathrm{kg}$ body weight, 3 times a week, Serum aspartate aminotransferase (AST) and serum alanine aminotransferase (ALT) were unchanged after rHu EPO treatment. We didn't find a statistically significant difference in serum albumin between first and second group $(\mathrm{p}=0.889)$, which means that EPO had no effect on serum albumin level.

Rhee and Erickson (2012) reported that protein energy malnutrition (PEM) diminishes immunoglobulin (IgA, $\operatorname{IgM}$ and $\mathrm{IgG}$ concentrations and cytokine production.

This is not the case in our study as serum albumin is within normal range.

In our study, hemoglobin (Hgb) levels were borderline higher in first group than second group $(\mathrm{p}=0.056)$. Also hematocrit (Hct) levels were borderline higher in first group than second group $(\mathrm{p}=0.056)$ and this was expected due to administration of EPO in first group.

Khurana et al. (2008) hypothized that the chronic inflammation as a result of $\mathrm{HCV}$ infection or the increased production from the regenerating liver cells causes increased circulating EPO causing improved Hct in these patients. Also, he reported that hepatitis $\mathrm{C}$ patients tend to have higher baseline hemoglobin and decreased need for EPO therapy on dialysis.

Recently, some studies and case reports indicated attenuated anemia in HD patients with $\mathrm{HCV}$ infection, and they previously considered this to be related to increased erythropoietin production after hepatic stimulation by chronic infection with hepatitis virus (Alasran et al., 2009).

In Lin et al., study (2008), there were increased $\mathrm{Hb}$ levels in chronic $\mathrm{HCV}$ infected patients with ESRD.

In contrast, Abdalla et al. (2000), reported a higher EPO requirement in $\mathrm{HCV}$ positive versus $\mathrm{HCV}$ negative patients that was a result of altered iron metabolism induced by chronic infection.

In our study, there was no statistically significant difference in white blood cells in blood ( $p=0.670)$ between the two groups, which means that erythropoietin didn't increase white blood cells count above normal, but it only normalized it.

Different circumstances such as chronic renal failure, hemodialysis process, chronic hepatitis $\mathrm{C}$ virus infection and various dietary restrictions that we practice with those patients influenced immune system and immunoglobulin production. We didn't find a statistically significant difference in IgM level in serum between first group and second group, which means that EPO didn't influence much IgM level production by stimulated B-lymphocytes by either EPO or $\mathrm{HCV}$ infection.

Little is known about the effect of ESRD on B-cell sub-populations (Pahl et al., 2010).

The increase in PMNL counts in CKD has been suggested to be a sign of pre-activation. The number of PMNL increasers in relation to the GFR decrease $(\mathrm{P}<0.0001)$ PMNL decreases with increasing serum C-reactive protein and IL-6 and decreased albumin, all associated with declining GFR (Sela et al., 2005).

In our study this was not the case, as we had lymphopenia but no undernourishment. Sardenberg et al. (2006) findings suggest that uremic toxicity plays an essential role in PMN apoptosis and that dialysis may correct or normalize apoptotic rates. 
ESRD and especially HD, is associated with B-cell lymphopenia (Kato et al., 2008).

$\mathrm{HCV}$ infection is associated with leucopenia in HD patients, is as common as in non-HD patients with liver cirrhosis (Ng et al., 2008). Chronic hepatitis $\mathrm{C}$ virus (HCV) infection is associated with $\mathrm{B}$ cell activation, although underlying mechanisms are unclear (Sugalski et al., 2010).

This is evidenced by an elevation in serum immunoglobulin isotypes; $\operatorname{IgG}$ and its subclasses $\mathrm{IgG}$, and $\mathrm{IgG}_{2}$ and $\mathrm{IgM}$. Mean serum IgM was increased in patients with HCV infection compared with healthy controls (Lotfy et al., 2006).

However, it has been documented that Ig levels, serum IgG isotypes and both IgM and IgA production are normal in dialysis patients (Hauser et al., 2008).

Starzyk et al. (1993) in their study on 10 patients with chronic renal failure treated with hemodialysis (HD) $\mathrm{T}$ and $\mathrm{B}$ cell populations were determined in peripheral blood, together with immunoglobulin concentration. There was no significant change in the concentration of IgA and IgM.

We didn't find in our study a significant difference in IgM level between males and females. This was not the case in Gonzalez et al. (2008) study who reported that IgM levels are higher in females than in males. Sex differences in immunoglobulins concentrations specifically high IgM levels in females, have been attributed to hormonal effects on B lymphocytes.

IgM didn't show in our study, any significant correlation to any of the measured parameters of the study including erythropoietin dose. To our knowledge, we are the first to study the effect of EPO on IgM level in HCV positive patients on regular hemodialysis.

In a previous study by Debska-Slizien et al. (2003), in order to find the influence of erythropoietin on immunological system of patients with chornic renal failure, it was found that treatment with EPO did not alter plasma immunoglobulin (IgG, IgM and $\operatorname{IgA}$ ), as well as total count of lymphocytes. In a previous study, by Costa et al. (2008), $50 \mathrm{HD}$ patients, 25 responders and 25 non responders to $\mathrm{rHuEPO}$, were compared to each other and to 25healthy controls. No statistically significant differences were found between the three groups of individuals concerning immunoglobulin serum levels (IgG, IgM and IgA).

In a previous study by Schaefer et al. (1992), who studied whether erythropoietin interferes with $\mathrm{B}$ cell function and the mechanisms of this effect, IgM production, which appeared to be normal in uremia, remained unchanged.

A retrospective study was done to determine whether $\mathrm{rHu}$ EPO treatment modulates the humoral arm of the immune system in MM patients. There was a significant increase in the levels of normal $\operatorname{Ig}(\operatorname{IgG}, \operatorname{IgA}$ or $\operatorname{IgM})$ in response to $\mathrm{rHu}$ EPO, during the 3-9 months from treatment initiation Gadassi et al. ( 2007) and Prutchi-Sagiv et al. (2006).

Data indicate a direct stimulant effect of erythropoietin on B- lymphocytes in endstage renal failure. Production of IgM was enhanced (Kimata et al., 1991).

These findings also show that the pharmacologic response to $\mathrm{rHuEPO}$ is a function of the dose.

Moreover, these effects were seen in concentrations much higher than that used in our study.

\section{Conclusion:}

ESRD with all its restrictions seems to protect patients from increased level of serum IgM due to $\mathrm{HCV}$ infection and erythropoietin therapy and subsequent cryoglobulinemia. Further studies at molecular level of B-cell functions are still needed to elucidate the causes of this protection.

\section{Acknowledgement:}

We would to express my gratitude to clinical pathology team of Shubra Municipal Hospital for their effort in this work.

\section{References}

Abdalla A, Owda A, Fedail H et al. (2000): Influence of hepatitis Cvirus infection upon parenteral iron and erythropoietin responsiveness in regular hemodialysis patients. Ren Fail; 31(5): 349-354.

Alasran K, SAbry A, Algareeb A, et al. (2009): Effect of hepatitis $\mathrm{C}$ virus on hemoglobin and hematocrit level sin Saudi hemodialysis patients. Ren Fail; 31(5): 349-354.

Awad A, St'uve O, Mayo M, et al. (2011): Antiglutamic acid decarboxylase antibody- 
associated ataxia as extrahepatic autoimmune manifestation of hepatitis $\mathrm{C}$ infection: A case report. Case reports in neurological medicine, Article ID 975152, 4 pages, doi: 10.1155/2011/975152.

Berglund B and Ekblom B (1991): Effect of recombinant human erythropoietin treatment on blood pressure and some haematological parameters in healthy men. J Intern Med 229(2): 125-130.

Bokle BC and Sepp NT (2010): Hepatitis C virus and autoimmunity. Autoimmune Highlights 1: 23-35.

Contreras A, Ruiz L, Cruz G, et al. (2007): End stage renal disease and hepatitis $\mathrm{C}$ infection: comparison of alanine aminotransferase level sand liver histology in patients with and without renal damage. Annals of hepatology; 6(1): 4854.

Costa E, Lima M, Alves JM, et al. (2008): Inflammation, $\mathrm{T}$ cell phenotype, and inflammatory cytokines in chornic kidney disease patients under hemodialysis and its relationship to resistance to recombinant human erythropoietin therapy. J Clin Immunol; 28: 268275.

Debska-Slizien A, Rutkowski B, Manitius J, et al. (2003): Influence of erythropoietin on immunological system of patients with chornic renal failure. Pol Merkur Lekarski 15(88): 326-7; discussion 327-329.

Diagnostic Automation, Inc (2009): Total human IgM assay. Diagnostic automation; available from http://www.rapid test. Com/index. Php?i=total-human-IgM-ELISA-Kit and $\mathrm{id}=51 \&$ cat $=11$. downloaded in $1 / 1 / 2011$.

Doumas B, Watson W and Biggs M (1971): Albumin standards and the measurement of serum albumin with bromocresyl green. Clin Chim Acta 31: 87-96

Fabrizi F, Lunghi G, Ganeshan S, et al. (2007): Hepatitis $C$ virus infection and the dialysis patient. Seminars in Dialysis, 20(5): 416422.

Fazi C, Dagklis A, Cottini F, et al. (2010): Monoclonal B cell lymphocytosis in hepatitis C virus infected individuals. Cytometry Part B; 78 B (Suppl 1): 561-568.

Foley RN and Collins AJ (2007): End stage renal disease in the United States: An update from the United States Renal Data System. J Am Soc Nephrol 18: 2644-2648.

Gadassi N, Prutchi Sagiv S, Oster HS et al. (2007): Elevated normal immunoglboulisn and stable M-Oprotein levels in multiple myeloma patienst on erythropoietin treatment. American society of hematology $49^{\text {th }}$ annual meeting December 8-11, Atlanta; GA tiny URL: http://www.mindcull.com/

abstract:e74c2d6a7053 dd6822ed3e4 31628a $70 \mathrm{~d}$.
Geara AS, Castellanos MR, Bassil C et al. (2010): Effects of parathyroid hormone on immune function. Clinical and Developmental Immunology, Volume 2010. Article ID 418695, 10 pages, doi: 10.1155/2010 / 418695 .

Gonzalez A, Alende G, Gude F, et al. (2008): Serum levels of immunoglobulins (IgG, IgA, IgM) in a general adult population and their relationship with alcohol consumption, smoking and common metabolic abnormalities. Clinical and experimental immunology, 151: 42-50.

Haag-Weber $M$ and Morl WH (1996): Dysfunction of polymorphonuclear leucocytes in uremia. Semin Nephrol, 16(3): 192-201.

hauser AB, STinghen AE, Kato S, et al. (2008): Characteristics and causes of immune dysfunction related to uremia and dialysis. Peritoneal Dialysis International 28(3): S1832S187.

Ito M, Kusunoki M, Mochida K, et al. (2011): $\mathrm{HCV}$ infection and B-cell lymphomagnesis. Advances in hematology, Article ID 835314, 8 pages.

Jang JY and Chung RT (2010): New treatments for chronic hepatitis C. Korean J Hepatol 16: 263-277.

Kalantar-Zadeh $K$ and Aronoff G (2009): Hemoglobin variability in anemia of chronic kidney diseases. J Am Soc Nephrol; 20: 479-487.

Kato S, Chmielewski M, Honda $\mathbf{H}$, et al. (2008): Aspects of immune dysfunction in end stage renal disease. Clin J Am Soc Nephrol; 3: 1526-1533.

Khurana A, Nickel Ae, Narayanan M, et al. (2008): Effect of hepatitis $C$ infection on anemia in hemodialysis patients. Hemodialysis international; 12: 94-99.

Kiechl S, Lorenz E, Reindl M, et al. (2002): Toll-like receptor 4 polymorphisms and atherogenesis. N Engl J Med 347: 185-192.

Kimata H, Yoshida A, Ishioka C, et al. (1991): Human recombinant erythropoietin directly stimulates B cell immunoglobulin production and proliferation in serum free medium. Clinical and experimental immunology; 85: 151-156.

Lifshitz L, Tabak G, Gassman M, et al. (2010): macrophages as novel target cells for erythropoietin. Haematologica 2010; 95(11): 1823-1831.

Lim WH Kireta S, Leedham E et al. (2007): Uremia impairs monocyte and monocyte-derived dendritic cell function in hemodialysis patients. Kidney Int., 42: 1138-1148.

Lin Y, Lin C, Lee C, et al. (2008): Chronic hepatitis ameliorates anemia in hemodialysis patients. Nephrology; 13: 289-293.

Liwoska KA, Bryl E, and Witkowski JM (2011a): Erythropoietin receptor is detectable on peripheral blood lymphocytes and its expression increases in activated $\mathrm{T}$ lymphocytes. Haematologica 201196(03): e13-e13. 
Liwoska KA, Jaswileuez A, Biryl E et al. (2011b): Erythropoietin as an immunoodulating agent. Nephro-Urol Mon 3(4): 247-251.

Lotfy M, El-Kady IM, Nasif WA, et al. (2006): Distinct serum immunoglobulins pattern in Egyptian patients with chronic HCV infection analyzed by nephelometry. Journal of Immunoassay and immunochemistry, 37(1): 03114.

Ng YY, Lin CC, Wu SC, Hwang SJ, Mo CH, Yang WC, and Lee SD (2002): Leukopenia and thrombocytopenia in hemodialysis patients with hepatitis $\mathrm{B}$ or $\mathrm{C}$ virus infection and non hemodialysis patienst with hepatic cirrhosis. Clin Nephrol; 57(4): 289-95.

Pahl MV, Sastry, Sepassi L et al. (2010): Effect of end stage renal disease on B-lymphocyte subpopulations, IL-7, BAFF and BAFF receptor expression Nephrol Dial Transplant 25: 205-212.

Perira BJ and Levey AS (1997): hepatitis C virus infection in dialysis and renal transplantation. Kidney Int; 51: 981-999.

Prutchi-Sagiv S, Glolishevsky N, Oster HS, et al. (2006): Erythropoietin treatment in advanced multiple myeloma is associated with improved immunological functions: Could it be beneficial in early disease? British Journal of Haematology; 135: 660-672.

Prutchi-Sagiv S, Neumann D and Mittleman M (2005): Erythropoietin as an immunotherapeutic agent: new uses for an old drug? The Journal for Innovatigve Ideas in Biomedical Research; 2: 587-596.

Rhee J. and Erickson T. , (2012): Erythropoietin stimulant and other blood doping methods, Ch 17, Medical Toxicology of drug abuse: synthesized chemical and psychoactive plants , by Donald G. Barcelous. John \& Wiley sons , published 2012.

Sardenberg C., Suassina P. , Andreoli MMC., et al. (2006): Effects of uremia and dialysis modality on polymorphonuclear cell apoptosis and function. Nephrol Dial Transplant; 21(1): 160-165.

Schaefer RM, Paezek L, Berthold G, et al. (1992): Improved immunoglobulin production in dialysis patients treated with recombinant erythropoietin. Int J Artif Organs; 15(4): 204-8.
Schumann G and Klauke R (2003): New IFCC reference procedures for the determination of catalytic activity concentrations of five enzymes in serum: preliminary upper reference limits obtained in hospitalized subjects. Clin Chim Acta, 327: 69-79.

Shin DM, Kwon YI, Choi SI, et al. (2006): Accidental ten times overdose administration of recombinant human erythropoietin ( $\mathrm{rHu}$ Epo) up to 318,000 units a day in acute myocardial infarction: report of two cases. Basic Clin Pharmacol. Toxicol; 98(2): 222-224.

Sela S, Shurtz-Surirski R, Cohen-Mazor M, et al. (2005): Primed peripheral polymorphonuclear leukocytes: a culprit underlying chronic low grade inflammation and systemic oxidative stress in chronic kidney disease. J Am Soc Nephrol; 16(8): 2431-2438.

Starzyk J, Sarnecka S, Bartelik S, et al. (1993): Subpopulations of T and B lymphocytes, rosette tests, levels of immunoglobulins in peripheral blood and NBT test in the initial period of hemodialysis conducted with cuprophan or cellulose acetate dialysers in patients with chronic renal failure. Wiad Lek 46(21-22): 817-823.

Sugalski JM, Rodriguez B, Mori S, et al. (2010): Peripheral blood B cell subset skewing is associated with altered cell cyling and intrinsic resistance to apoptosis and reflects a state of immune activation in chronic hepatitis $\mathrm{C}$ virus infection. J Immunol 185: 3019-3027.

Tabacco A, Meiattini F, Moda E, et al. (1979): Simplified enzymic/colorimetric serum urea nitrogen determination. Clin Chem 25: 336-7.

Trevizoli JE, de Paula MR, Ribeiro LF, et al. (2008): Hepatitis $\mathrm{C}$ is less aggressive in hemodialysis patients than in nonuremic patients. Clin J Am Soc Nephrol 3: 1385-1390.

William J, Saad N, Salib M et al. (1998): The acute effect of intravenously administered recombinant human erythropoietin on the immune response of uremic patients maintained on regular hemodialysis. Artif Organs 22(3): 192-196.

Yatzidis H (1974): New method for direct determination of true creatinine. Clinical Chemistry, 20(9): 1131-1134. 


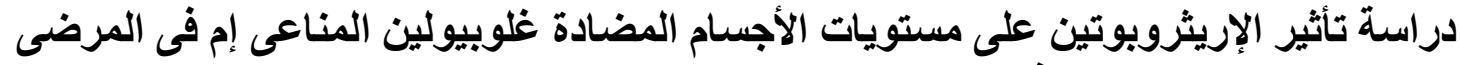

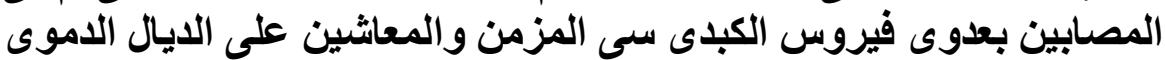

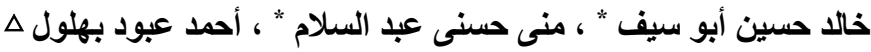

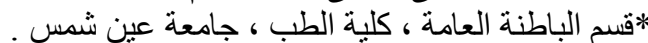

ه قسم الباطنة العامة ، مستشفى شبرا العام ، وزارة الصحة ، جمهورية مصر العربية

كل من مرض البولينا والديال الدموى يسبب إحباط للمناعة فى المرضى المصابين بالفثل الكلوى

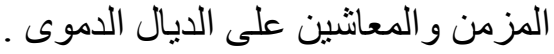

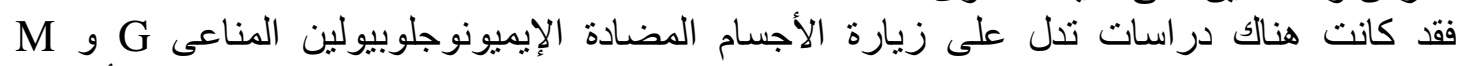

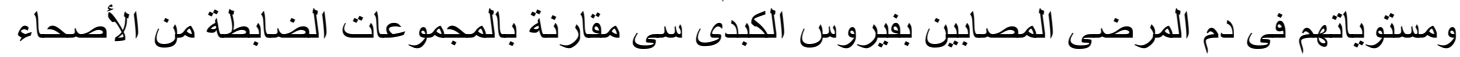

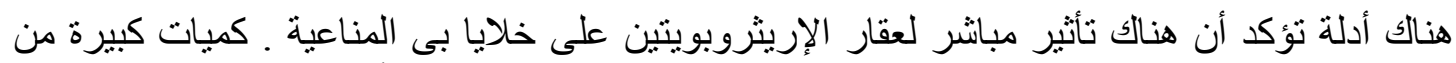

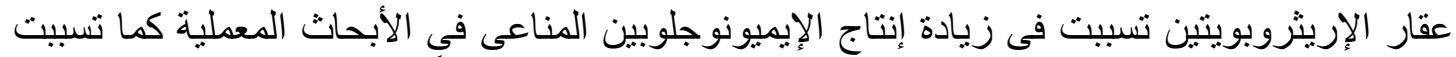

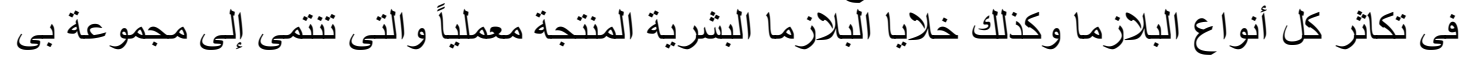

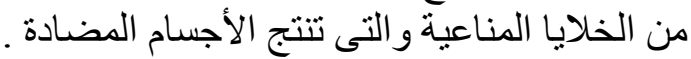

هذه الدراسة تم الجرائل :

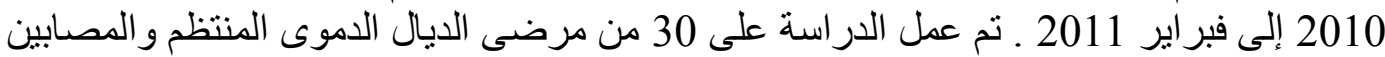

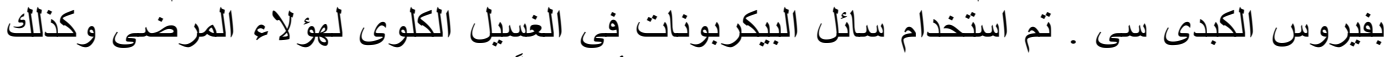

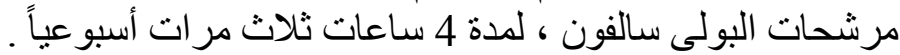

ه تم تقميم المرضى الأول : 15 مريض مجوعتين : يستخدمون عقار الإريثروبويتين فى حدود جرعة

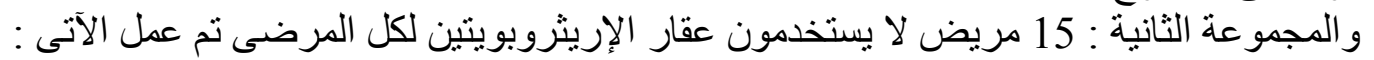

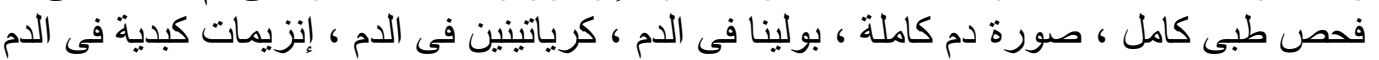

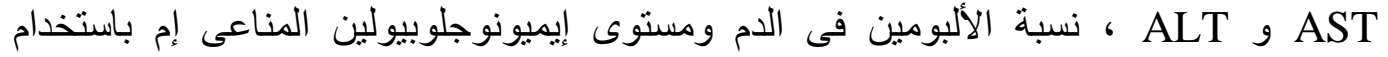
ELISA

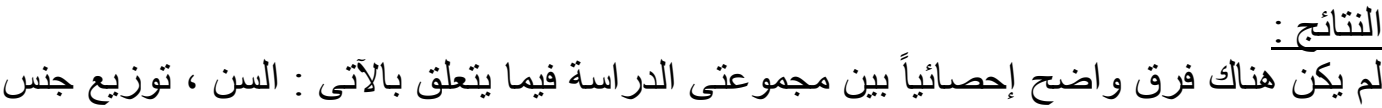

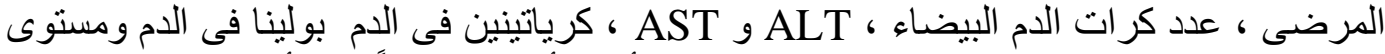

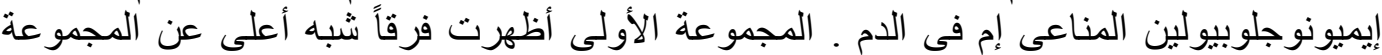

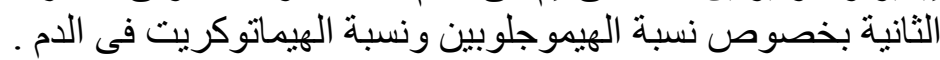

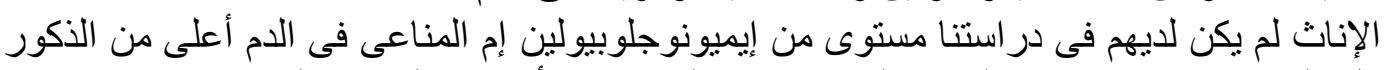

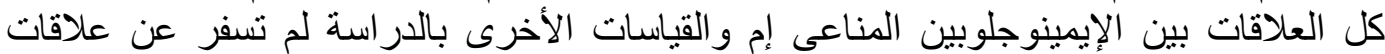
إيجابية مباشرة أو سلبية لهات أهمية إحلوبين الحصائية .

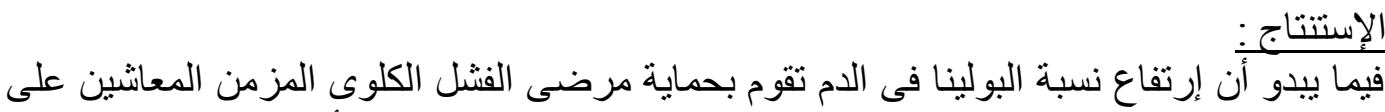

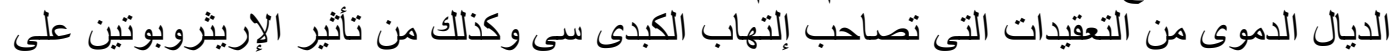

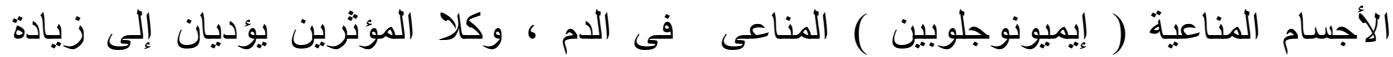
ايميونوجلوبيولين المناعى أم فى الدم ـ الدين 